\title{
Bioeconomy 101: Making rubber tyres from dandelions
}

Written by: James Philp, OECD Directorate for Science, Technology and Innovation

Last update: 2 March 2020

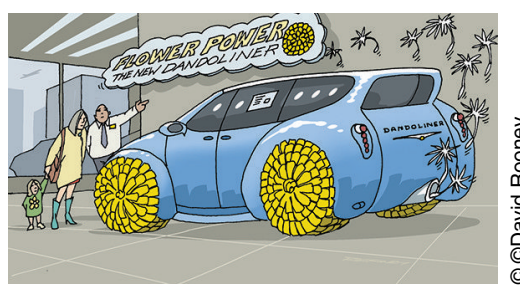

Bioeconomy 101: Making rubber tyres

from dandelions I Illustration for:

Bioeconomy 101: Making rubber tyres

from dandelions

Moving beyond a petroleum-based economy is not just about choosing alternative sources of energy. It is about rethinking almost everything around us. The fleece you're wearing, for example, is made from the same oil-based chemical as antifreeze or engine coolant. This is where green chemistry comes in. Advances in biotechnology are allowing us to manufacture fabrics, plastics, fuels and chemicals from bio-based resources using renewable resources.

Instead of oil feedstock, as in conventional manufacturing, plastic can be made from fermentation, rather like brewing beer. Bio-based latex car tyres can be made from dandelions and carpets from sugar. Right now we are still deeply dependent on petroleum products. But the idea of making chemicals in microorganism factories instead of oil refineries is taking off. This will mean a cleaner, more sustainable future for manufacturing.

\section{A vision of bio-based manufacturing}

Industrial biotechnology is starting to change the consumer goods we buy. Water bottles will soon be made partially or completely from bio-based carbon rather than fossil fuel-based plastic, for instance. Graphene is another key material of 
the future: it conducts electricity better than copper. Right now it is still expensive but a research group has perfected a simple process that turns soybean oil into graphene, which will make it ideal for consumer electronics. Extremely strong spider silk is another biotech invention. Though there are technical barriers to its production from a microorganism, they are now being overcome. Among the newer possible applications of spider silk are high-tech microphones in hearing aids and cell-phones.

What would a bio-based production system look like? Biorefineries make fuels, chemicals and electricity from residual organic biomass, and under certain conditions, also from food crops. This can range from expensive purified sugar to waste materials such as scrap lumber, manure, straw, or the organic domestic waste in your waste bin. By-products and side streams from biorefineries could, themselves, generate new industrial ecosystems in a more circular economy. In converting waste of different kinds into usable products, biotechnology would decrease landfill, reduce carbon footprints, and create a more resource-efficient economy.

It is likely that biorefineries will be small- to medium-scale facilities in rural or semi-rural areas with ready access to biomass materials. Such a biotech transition holds promise on several fronts, including local jobs, rural regeneration, smart specialisation, circular economy and reindustrialisation. It also fills in many of the blanks as to how to make progress on at least half of the United Nations' Sustainable Development Goals by 2030.

\section{Problems and roadblocks}

Bio-based manufacturing can become a reality but many hurdles must be cleared first. For instance, increased demand for biomass may put pressure on land used to grow food crops, a concern that arose a few years ago when the production of biofuels accelerated. For the past decade, the OECD has been working on biomass sustainability issues, developing standards for international trade in biomass. In 2013, an OECD Recommendation was issued, encouraging members to develop and implement national frameworks for assessing the sustainability of bio-based products. It lists the considerations OECD member countries should take into account when making such assessments. It also recommends using life cycle analyses whenever possible; that is, the analysis of everything that goes into a biotech process such as fuel and raw materials, everything produced by the process including different wastes, and the environmental impact of both sides of the process.

There is also the issue of regulatory and technical barriers to a bioeconomy. While using waste for bio-production is resource-efficient and avoids land-use tradeoffs, it requires regulatory changes. Right now, waste is predominantly defined as something that must be discarded rather than something to be re-used.

Redefining waste would be an important step. In the technical realm, policies that 
encourage public research on and development subsidies for bio-based production are key. So would policies that smooth the way for public-private partnerships to build biorefineries, which are, as yet, high-risk investments. Politically, there is still too much support in many parts of the world for marketdistorting fossil fuel subsidies. Carbon pricing and the removal of these subsidies would help us move on from fossil fuel dependence and on to cleaner, more effective, technologies instead.

The bioeconomy is an alternative to our current "take, make and dispose" way of doing things. Industrial biotechnology can replace petroleum, make use of wastes, and foster cleaner manufacturing. With the right policies in place, biotech could jumpstart a more circular economy and help us face the grand challenges of climate change, soil destruction, water and energy security, and resource scarcity.

@OOECD Observer April 2018

\section{References}

OECD (2018), Meeting Policy Challenges for a Sustainable Bioeconomy, OECD Publishing, Paris, http://dx.doi.org/http://dx.doi.org/10.1787/9789264292345-en

https://legalinstruments.oecd.org/Instruments/ShowInstrumentView.aspx? InstrumentID=283\&Lang=en\&Book=False https://legalinstruments.oecd.org/ Instruments/ShowInstrumentView.aspx?

InstrumentID $=283 \&$ Lang=en\&Book=False 